\title{
The factors that influence a lawyer's use of and ability to develop effective electronic information seeking behaviour
}

by

Submitted to the School of Information Management,

Victoria University of Wellington

in partial fulfilment of the requirements for the degree of

Master of Information Studies

February 2014 


\section{Acknowledgements}

I would like to thank the many people who have been generous to me giving their time and their support towards this research project. In particular, special thanks are due to the following people:

To my supervisor Dr Brenda Chawner, who has given me helpful advice and been very supportive throughout this project.

To the lawyers who participated in my research, I know you are all very busy and I appreciate the time you gave me.

To the partners and employers who allowed me to come into their workplaces and interview the lawyers working for them.

To those who helped me to find the participants for this research.

And to my husband Chris and my children Dominic, Oliver, Joseph and Catherine who have supported me throughout my study. 


\section{Contents}

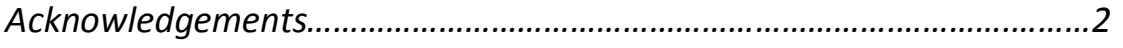

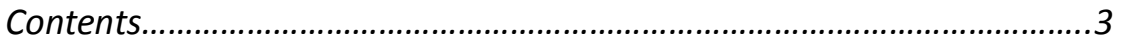

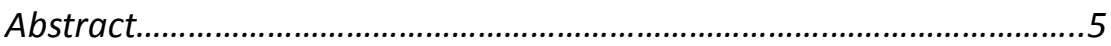

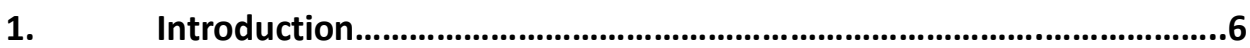

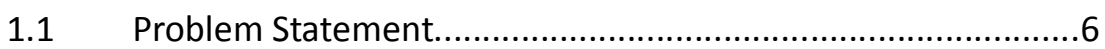

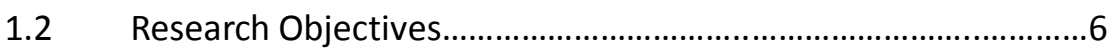

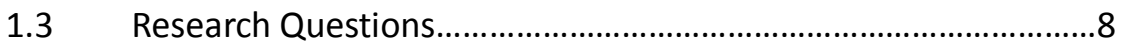

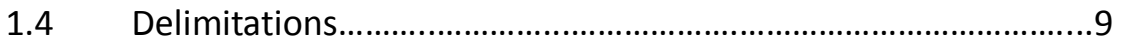

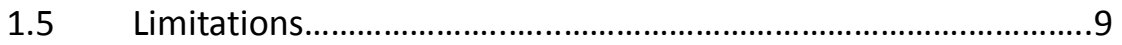

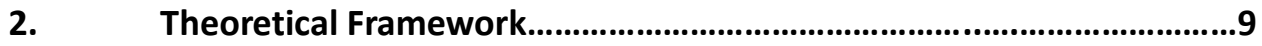

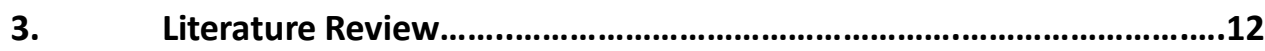

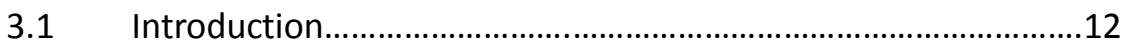

3.2 Factors Personal to the Individual that Impact of their Electronic Information Seeking..................................................12

3.3 The User-Orientated Approach - Observations on how an Individual Undertakes Electronic Research.................................15

3.4 Why an Innovation is, or is not, Adopted....................................16

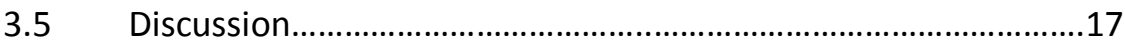

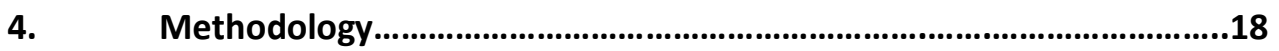

4.1 Study Participants.................................................................

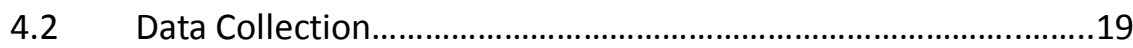

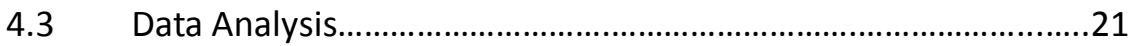


5.

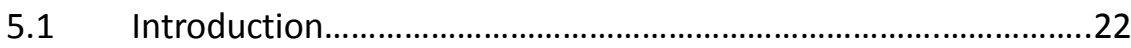

5.2 Participant Demographics.........................................................22

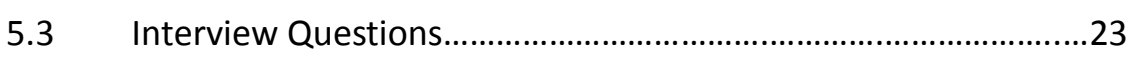

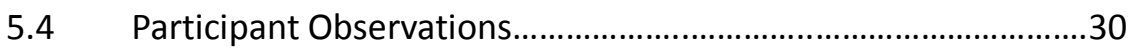

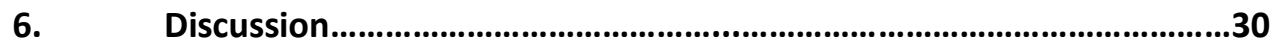

6.1 The Impact of Cognitive Features...................................................30

6.2 The User-Orientated Approach.....................................................33

6.3 Rogers' Diffusion of Innovations Theory .......................................34

6.4 Findings of this research compared to previous studies..............36

7. Conclusion and Recommendations.....................................................38

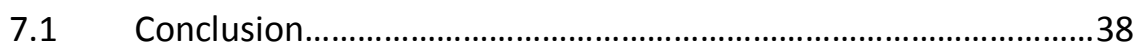

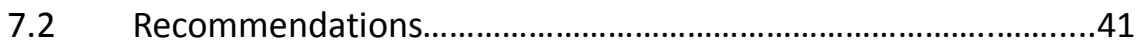

7.3. Areas warranting further study ..................................................43

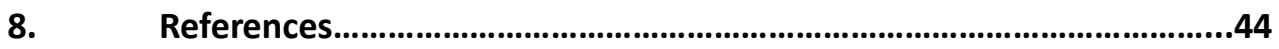

Appendix A: Email Request for Lawyer's participation in interviews................48

Appendix B: Information Sheet.....................................................................50

Appendix C: Consent Form...........................................................................

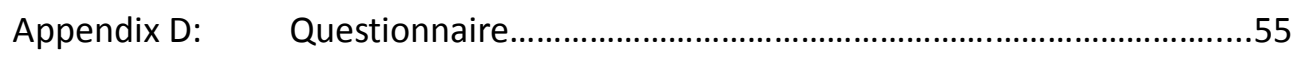

Appendix E: $\quad$ Semi-Structured Interview Questions.........................................56

Appendix F: Interview Follow-up Questions...................................................57

Appendix G: $\quad$ Participant Observation Tasks....................................................59

Appendix H: $\quad$ Analysis of Themes Sample........................................................60

Appendix I: $\quad$ Characteristics of Participants sample...........................................61 


\section{Abstract}

Research Problem: The purpose of this research was to discover the factors that influence a New Zealand lawyer's use of and ability to develop effective electronic information seeking behaviour. There have been no previous studies undertaken in New Zealand to understand the cognitive reasons and the reasons directly related to the resources themselves that impact on why lawyers do, or do not look for information effectively from electronic resources.

Methodology: A phenomenological study design was used in order to understand an event from the viewpoint of the participants. Nine New Zealand lawyers participated, providing demographic information and taking part in semi-structured interviews. In addition two of these lawyers took part in a further participant observation.

Results: The results indicated that factors personal to the applicant such as their previous training, electronic experience, personality and age have an impact on their ability to develop effective electronic information seeking behaviour. In addition external factors such as cost, time and lack of access directly related to electronic resources also have an impact.

Implications: Based on the findings of this report it was found that electronic resources were considered to be an important part of a lawyer's work and gaining increasing significance. However not all lawyers have the ability to make full use of these electronic resources. Therefore it is important that lawyers are provided with the opportunity to undertake appropriate training and to access high quality electronic resources.

Further study needs to be undertaken to look at strategies and training methods required by lawyers and their employers to improve these skills.

Descriptors: New Zealand Lawyers, Legal Research, Information Seeking Behaviour, Online Databases, Computer Literacy, Training 


\section{Introduction}

The ability to undertake electronic research has become a vital skill in workplaces. In New Zealand, lawyers are expected to provide a high quality service for their clients. However, although there is legal material available to them on the internet, many lawyers are unable to fully utilise these resources. This research explores the factors that influence a New Zealand lawyer's ability to obtain quality information through electronic resources. It looks at the personal characteristics of the lawyers themselves and factors specific to the electronic resources that influence the lawyer's use of these.

The lawyer's provide their views on the positives and negatives about using electronic resources and also their opinions on how they consider any issues can best be addressed. In accordance with this, this report then makes recommendations on the best course of action to overcome the problems raised. i.e. providing targeted training.

Whilst this report looks at the factors that influence a New Zealand lawyer's use of electronic products and their views on overcoming any problems, it does not consider in detail specific methods to overcome any issues raised, this is an area that would need to be explored in a further study.

\subsection{Problem Statement}

Since the internet become available to the public in the early 1990s, it has become increasingly integrated into modern society. It now occupies such a central role in information provision that many workplaces cannot afford to be without it.

Technology exists for the primary purpose of being able to be used to achieve a required purpose. Therefore it is important for a business to put into practise strategies for harnessing electronic resources and using them effectively. Computer technology is such a valuable asset yet it is often not being used to its full potential.

Information is available in New Zealand to lawyers through electronic products, including an ever increasing amount of free and subscription websites. However with such advances in technology, obtaining information from electronic resources requires lawyers to develop a new set of skills. 
The ability to obtain quality information from electronic resources is a two-part factor. The first part is to discover the reasons why lawyers do or do not look for information effectively from this source. People approach information seeking in many different ways. There have been no previous studies undertaken in New Zealand about how lawyers decide which type of source to use, if any.

The second part is to then assess how lawyers go about finding relevant information when they do start looking for it electronically. There have been previous studies undertaken in New Zealand whereby the search techniques of lawyers have been studied. Pearson (2008) undertook a study comparing the differences in search techniques between law librarians and novice searching lawyers. However this current research goes a step further, ascertaining the lawyer's views on strategies and training methods to improve these skills.

According to Pearson (2008) not all lawyers have the computer literacy skills to take full advantage of electronic resources. There can be a number of reasons for this. Several studies have shown that a person's characteristics could affect their ability or willingness to use electronic services. These could include factors such as their age, gender, intelligence or confidence. Studies by Shih \& Venkatesh (2004), Childers (2003) and Chawner (2008) all discuss the impact of personal characteristics on the use of information technology by individuals.

Secondly lawyers educated in the post internet era have been exposed to computers during their training and therefore probably have some familiarity with using online services for research purposes. However their level of formal training may have been minimal. Many lawyers will be self-taught and many others will have learnt the minimum to get by. Together with lawyers who studied prior to the internet revolution they may lack sufficient computer expertise to fully utilise the services available to them.

Without this expertise lawyers may have been unable to develop effective information seeking behaviour, and may also have inadequate domain knowledge to be able to fully utilise electronic products. Improving information literacy is vital in order for them to confront their computer anxiety. By assessing lawyer's reactions to using computers, educators can develop materials and processes for teaching computer skills that will decrease internet anxiety. 
Not all lawyers will have access to the services of an information professional to undertake their research for them. This may be because they are working in a small law firm, or as an in-house lawyer, or even for themselves. Although the Law Society provides a legal research service where lawyers can pay a fee in return for research being done on their behalf, lawyers may choose not to take this up, for a variety of reasons. It is therefore necessary for them to be able to obtain their own quality electronic information. If employers are expecting to have a top class workforce then understanding and resolving these issues is vital. In order to be a learning organisation both lawyers and their employers need to know how they learn new skills in order to train them to be more computer literate (Goad, 2002).

\subsection{Research Objectives}

The objective of this study is to develop an understanding of what factors influence the use by lawyers of electronic resources. It intends to show that obtaining high quality information from electronic research is not just a process of entering correct search terms but instead a broader approach is vital. This research looks at why and how lawyers learn electronic information seeking skills and how lawyers with varying characteristics interact with and use electronic resources. In addition it aims to explain how and why a technology is used by a culture, in this case, lawyers.

Both the lawyers and if relevant their employers can then use this knowledge, in order to develop strategies and training programmes, with the aim of improving their computer literacy if this is required.

\subsection{Research Question}

After taking account of the literature on this topic the following research question has been developed:

"What factors influence a lawyer's use of and ability to develop effective electronic information seeking behaviour? 


\subsection{Delimitations}

- This study is restricted to practising lawyers in New Zealand.

\subsection{Limitations}

- This study is limited in scope. It is based on a convenience sampling method of nine lawyers. As this is a small number of people being studied, the results may not be generalisable.

- As this study is only researching lawyers, it is a one off study, concerning a unique workforce. Therefore applying these findings towards other professions and industries should be undertaken with this in mind.

- Artificial search tasks were created for this study which may lack some realism. These are specific defined requests, created in an unnatural environment and structured in a way that removes the element of uncertainty that exists in real life situations.

- Although all nine lawyers gave an oral description of how they would undertake a search task only two lawyers were observed doing so. A larger sample of lawyers undertaking the participant observation would improve the reliability of this study.

- The interviews rely on each lawyer's personal interpretation of the question and also their memory of their previous actions, which may be flawed.

\section{Theoretical Framework}

In 2004 Peter Ingwersen, Professor of Information Retrieval at Abo Akademi University, Norway and Kalervo Jàrvelin, Professor of Information Studies, University of Tampere, Finland published a book, The turn: Integration of information seeking and retrieval in context (2004). In this they develop a theoretical framework where they integrate 
information seeking and information retrieval into one. This theory builds on Ingwersen's earlier research contained in his book, Information Retrieval Interaction (1992), where Ingwersen develops the idea that a combination of a traditional approach, a user-oriented and a cognitive approach are necessary in order to obtain optimum information retrieval for the searcher.

In this earlier book Ingwersen theorises that the traditional approach to information retrieval is not complete enough to create the full picture of how individuals search for and retrieve information from electronic resources. This approach is centred on entering the correct search operators and terms into an electronic system, in order to obtain the required results. The problem with the traditional approach is it is solely concerned with developing requests and query formulations by using the correct language. Although this is an important part of information retrieval, it takes the query or request expression for granted, without any consideration of how or indeed if a user can get to this point in the first place. In this traditional information retrieval approach the user hardly exists.

Ingwersen states this approach to information retrieval is very technology focussed, concerned only with the information retrieved by each search and whether this directly related to the search terms entered, with no consideration given to the needs of the end-user and whether this information they obtained was satisfactory for them. He state that whilst the traditional approach is still necessary, it needs to be combined with the user-orientated and the cognitive approach to enable a searcher to obtain the best possible result in information seeking.

The user-orientated approach is over time becoming integrated with the cognitive approach. The user-orientated approach focusses on the psychological and behavioural communication of information between the user and the system. This uses real life investigations of search behaviour to understand common patterns. The cognitive approach focusses on the individual cognitive, motivational and emotional activities inherent in all areas of information retrieval. It also looks at the social environment surrounding the act of retrieval.

Ingwersen and Jàrvelin emphasise that individualistic cognitive and linguistic as well as socio-behavioural processes are heavily involved in influencing information retrieval interaction. They theorise that for information seeking and retrieval to take place 
"during communication of information any actor is influenced by their past and present experiences and their social, organisational and cultural environment" (p.25). They also make the point that information is situational and contextual. They state that a myriad of factors have an impact on the whole process. They list factors such as social and organisational domains; knowledge; behaviour; culture; goals; purpose; individual preferences; emotions; expectations; and experiences as all being relevant to this process (p. 28).

Ingwersen states that it is one of the aims of his research to reinforce methods and teaching aids which may improve the quality of the information transfer process conducted by librarians/information specialists ( $p 103)$.

Whilst Ingwersen and Jàrvelin are looking at the human side of obtaining optimum information retrieval from electronic resources there is another aspect of this current research that is not covered by their theory. This concerns the issue of why lawyers might either be using computer technology sporadically, or not at all.

Everett Rogers (1962) Diffusion of Innovations theory looks at why an innovation such as computer technology is, or is not taken up. In his book, "Diffusion of Innovations", published in 1962 he theorises that there are four main elements influencing the spread of an idea, which are: the innovation; communication channels; time; and a social system. Rogers defines the following characteristics of innovations as reasons why users may adopt or reject them:

- Relative advantage: i.e. how this innovation will improve the current situation.

- Compatibility: How easy it will be to assimilate this innovation into the user's life.

- Complexity or Simplicity: How easy is it going to be to use it?

- Trialability: How easy it will be to experiment with it before introduction of it.

- Observability: The extent an innovation is obvious to others.

Rogers' theory of innovation has been used as a framework for numerous studies across many disciplines and is appropriate for use in this research as a framework for looking into the reasons why lawyers may or may not adopt computer technology within their workplaces. 


\section{Literature Review.}

\subsection{Introduction}

This chapter discusses the literature that is relevant to the factors that influence a lawyer's use of electronic resources. It is divided into three main sections in accordance with the theoretical framework of Ingwersen and Jàrvelin (2004), and Rogers (1962). These three sections are then divided into more detailed sections dealing with specific factors that impact on a lawyer's ability to develop effective electronic information seeking behaviour.

\subsection{Factors personal to the individual that impact on their electronic information seeking.}

Computer technology has become an integral part of our society and is embedded into all workplaces. Yet to date there are no qualitative studies undertaken in New Zealand of the effects of a lawyer's cognitive style, personal characteristics and previous searching experience on their use of and ability to develop effective electronic information seeking behaviour.

\section{- Cognitive factors.}

Ingwersen (1992) found that there is a big gap between the information needed by users and the information obtained. He states that $22-40 \%$ of information requests differed from needs (p.98). Studies of end-user satisfaction are needed to see whether they are obtaining the results that they set out to achieve through electronic resources.

Childers (2003) points out that although information technology is constantly changing and so theoretically the technology we are using now may well be outdated shortly, becoming information technology literate is more about learning to think in the logical fashion necessary for computer interaction. So computer literacy is about the way we think and interact with the computer rather than learning about one specific information technology type. There is also the perception that if the use of the technology does not achieve the required goal in the way required, then this would lead to reluctance in its uptake. 


\section{- Experience}

However while results have shown that cognitive style significantly influences search performance of novice searchers, the influence is reduced in those that have online database experience (Palmiquist and Kim, 2000).

Jacobson and Fusani (1992) found that search experience and system knowledge were the critical factors in obtaining a successful search, rather than domain knowledge. This means that despite the fact lawyers are skilled in the law, in order to obtain the information that they require electronically they have to have a suitable level of knowledge of how to undertake a search. This may be a reason why experienced lawyers are reluctant to search for information if they have encountered limited success in the past.

Poynton (2005) found that explicit training in computer skills improved user's ability to obtain what they required, as well as their general computer literacy. He stated that although training is important, practise is the biggest reason behind improvement. Users need to search regularly to maintain good searching skills.

\section{- Age}

Hollis-Sawyer and Sterns (1999, as cited in Poynton, 2005) found that older adults performed significantly better when training was guided by self-directed, goal specific tasks, than when more general feedback was employed.

Chawner (2008) found that age is a significant contributor in determining how many different technologies an information manager uses regularly. She found that when introducing a technology into a workplace it would be most beneficial to have a younger members of staff undertake this. However she also found the most active technology users were between the ages of 31 and 45 . This would indicate that once they have obtained a suitable level of expertise this age group would use these skills.

\section{- The impact of training on an individual's electronic search behaviour}

Price (2006) found that seven out of ten employers thought that the information technology skills of their workforce had a significant impact on the success of their 
business. Yet only one in five companies was intending to do computer training for their staff in the following year. Price states that the research shows a gap in employee's skills in this area and the skills their employers need them to have.

\section{- Goals and purpose of training}

Price (2006) says that in order to maximise skill training it should be not undertaken as a "sheep-dip" (p.1) approach but rather build upon their current skills level and the specific requirements of the job. She says that there are currently online assessment tools available to businesses which help a workplace to determine what electronic skills they have, what they need and how to build a strategy to obtain these skills. She also discusses the more formal qualifications in these skills which are available in this area.

Childers (2003) states that to improve staff computer skills we should undertake training that is more than basic. Workforces must put money and time into this and also keep up with technological changes. It should be a "necessity not a luxury and mandatory not voluntary" (p4). It is important to have comprehensive training in order that employees don't learnt everything through rote memory, but instead establish a level of understanding where they are able to adapt to changes in technology easily.

The University of Minnesota Libraries established a taskforce in 2005 to develop a list of core information technology skills that they expected all staff to be able to perform. They provided staff with a self-assessment questionnaire to complete outlining their personal view of their computer skills. They then used this information to tailor the training and professional development of staff to their individual needs in order to bring them up to the expected level (Eells, 2008).

\section{- The individual's motivations and expectations of training}

In this research undertaken by Eells (2008) he considered creating an online selfassessment test and found that existing versions of these lessened the cost of having to create one yourself. His research promoted the idea of self-assessment of computer ability above being tested by other people in order to reduce any negative feelings towards this process. He wanted staff to know that the reason for undertaking this exercise was for their own self-improvement allowing them to "exceed and excel in their professional life" (p. 24). 
However incentives can be given to help staff reach their full potential. For example linking computer proficiency to pay rises or promotions has been found to be a good incentive (Jennings, 2005). She created an organizational flow chart to determine individual's computer needs. This involved the following process: Analyse the workassess user's needs - collect data - define the computer course objectives - develop performance measures - evaluate and keep records of results. If employees felt that they already had the required performance for an area then they could undertake a post-test assessment to see whether they were proficient enough to bypass this course.

Pre-test and post-test assessments helps check that the course is doing what it set out to do and also ensures consistency if there are different trainers or different training locations. This also allows a workplace to see how each staff member has improved throughout the process (Jennings, 2005).

\subsection{The user orientated approach - observations on how an individual undertakes electronic research}

In a New Zealand study undertaken by Robinson (1997) on lawyers' searching techniques she found a reluctance for in-depth searching as the lawyers tended to only use simple search tactics such as Boolean AND and not Boolean OR. They were therefore not able to retrieve all the relevant data required from subject searches.

Debowski (2001) also examined the difficulties encountered with search strategies. These studies are both still relevant because they are looking at how the user interacts with the system in order to explore the individual's cognitive approach to information seeking, rather than the computer system's search interface being used. Debowski explored the means by which searchers devise their strategies by studying 48 undergraduate students in Western Australian universities. The students put very high levels of effort into the searching process but focussed on inputting data rather than planning the process. Often they entered the same term repeatedly and there was little evidence that search quality assessment or any forethought was undertaken by the searchers. This study shows that those left to create their own searching techniques are probably going to undertake poor quality searches. 


\subsection{Why an innovation is, or is not adopted.}

In addition to the emotional reasons influencing a lawyer's use of electronic resources there are also attributes of an innovation intrinsic to it, that impact on the likelihood of it being adopted. Rogers (1962) outlines these in his Diffusion of Innovations theory.

Non-adoption of technology may be because it is associated with a belief that the innovation is not needed (Patsiotis, Hughes \& Webber, 2013). This study discusses the differences between non-adoption and actual resistance to technologies. In addition other barriers, such as technological ones impact on its uptake (Chawner, 2008).

\section{- Usefulness vs. Ease of Use}

In Monsuwe et al (2004) it was found that the usefulness of information technology was a greater factor in adoption than ease of use. Davis's (1989) technology acceptance model, (TAM) expounds on this, theorising that ease of use and usefulness are the key determinants of whether a user will adopt technology. He states that other factors such as user attitudes and personal traits are all secondary to this.

In order to tell whether a new technology has become part of the framework, not only do we have to look at its adoption, but also its use over a period of time. This can be a prolonged period of time because computer technology is complex and evolving. Shih \& Venkatesh (2004) undertook research on this in the marketing domain. They were concerned with the evolving nature of use of various products, including computer hardware and software. They considered how often it is used and whether it is used for a variety of purposes. They found that the uptake of this technology is influenced by an individual's propensity to adopt technology as well as the perceived essentialness of it.

Eveland (1986) found that after a new technology is introduced, if it is not considered to have intrinsic value it will not become embedded in the organisation. It has to provide such a level of value to the person using it that they would not consider going without it.

\section{- Institutional barriers to use}

Chawner (2008) found that institutional barriers to the uptake of web 2.0 in the workforce were raised as the most regular problem. Whilst employees may be keen and able to use these services, their business information technology restrictions often limit 
their access to these tools. This is often caused by security reasons and may be very difficult to change. According to Eveland (1986) most organisation decisions are not decided on the basis of the technology but rather on 'finance, personal, scheduling and resource management' (p. 11).

\subsection{Discussion}

As most of the studies discussed in this review are not New Zealand studies and come from readings covering a wide range of areas, they need to be generalised with caution. However there are some common themes emerging here, namely that a myriad of factors all play a part in the quality of electronic research undertaken. Search experience, age and previous training are all shown to be important in an individual's ability to undertake electronic research. In addition several factors motivate an individual to improve these skills. For example an individual's willingness to undertake training is tied to them requiring training to not be general, but to be specific and relevant to their work needs and current level of ability.

In addition many factors that impact on an individual's electronic research are outside their control. For example, technological barriers such as deficient internet connections or cost of resources can mean services that would be of considerable use to them are not available.

This current research looks at whether these factors are also relevant to electronic research undertaken by lawyers in New Zealand and whether any additional factors also have an impact. Only three New Zealand studies are contained in this review and although two relate specifically to New Zealand lawyers (Robinson, 1997; Pearson, 2008) they both focus on how a lawyer physically undertakes a search, rather than the factors influencing this. This literature review therefore does not contain enough detailed information, specific to this workforce, to draw conclusions without further study in this area. 


\section{Methodology.}

Ingwersen's (1992) theory expounds the idea that information retrieval can take a traditional approach, a user-orientated approach and a cognitive approach. He states that these latter two are interconnected and this current research is going to use this user-orientated, cognitive approach as a framework. It will show that this framework is an integral part of why lawyers do or do not use electronic resources.

Technology is directly connected to the purpose it is to be used for and its uptake relates to how people think and feel about it. In accordance with Rogers' (1962) Diffusion of Innovations theory this research also studies the integration and implementation of information technology in the workplace and assesses how lawyers deal with this. This research aims to discover themes from the answers given by the participants in accordance with Ingwersen and Jàrvelin and Rogers' theories.

This research aims to understand an event from the viewpoint of the participants concerned and therefore will use a phenomenological study design. Phenomenology studies what people experience and the ways that those experiences can be understood and then how these experiences help a person to make sense of the world (Bryman, 2008). It is a description of a person's experience as lived by them, in the context of their world (Finlay, 2009). It is derived from Edmund Husserl's philosophical phenomenology and is both a philosophy and an approach to research (Husserl, 1936).

Using a phenomenological design means that we can address the factors influencing computer technology uptake by lawyers in New Zealand and then come to a conclusion over the best strategies and training methods for addressing any issues raised relating to their use of electronic resources in their workplaces.

\subsection{Study Participants}

This study used a purposive sample of nine lawyers in New Zealand, in order to give a small but in-depth picture of how lawyers obtain computer literacy skills. Purposive sampling is the selection of a sample on the basis of its contribution of information rich cases for in-depth study. The sample is chosen on the basis of who is appropriate and relevant for this research (Patton, 1990). 
To make this study more generalisable a diverse demographic range of lawyers participated. This involved lawyers from early in their careers, to lawyers who had worked for over twenty years; men and women; lawyers from several different regions in New Zealand; and also lawyers working in a variety of different workplaces, ranging from working for companies as in-house lawyers, to self-employed, or working for a law firm. None of the participants involved in this study had an in-house library with specialist law librarians to undertake research on their behalf.

A snowball sampling technique was used where initially a small group of participants from a range of workplaces were contacted. This is a type of convenience sample in that the initial lawyers to be approached were current contacts of the researcher. Through these lawyers further contacts were obtained, in order to create a more diverse sample. All of the lawyers contacted were emailed requesting their permission to participate in this research (See Appendix A).

In recruiting these participants, permission was first sought in accordance with University regulations and the Human Ethics Committee, before these individuals were approached and invited to take part in the research. In addition each participant was given a bottle of wine as a thank you for their participation.

\subsection{Data Collection}

When undertaking data collection and analysis it is vital that the participants trust that the person undertaking the research will only use the information obtained in the manner that they have been advised it will be used for. Participants have to feel comfortable that any mistakes and errors they make not directly related to the research will not be disclosed. Therefore before this research began the participants were advised of the purpose and objectives of the investigations and their agreement obtained regarding major goals. All the processes of the research were explained at this stage, such as what happens to the data collected, how it is analysed and what the results will show. Information sheets and consent forms were approved and then provided to the studies participants prior to their interviews (See Appendix B and C). The participants were then given results prior to other people.

To gain an in-depth picture of lawyer's attitudes to computer technology three methods of data collection were employed. All participants were emailed a short questionnaire containing questions relating to their demographic background and self-assessment of 
their previous search experience. They were asked to complete this and return it prior to the interview (See Appendix D).

Secondly all participants were asked to take part in a semi-structured recorded interview, answering a series of questions. These questions were designed to answer the overarching research question and covered: the lawyers' experience of and views on undertaking electronic research; their cognitive learning styles; how they would structure an appropriate computer search strategy; any barriers they considered restricted their use of electronic resources; and their views and experiences on undertaking training (See Appendix E).

In addition a series of follow up questions were asked, designed to elicit the maximum amount of information to answer the Research Question (See Appendix F).

For the interviewees that were not geographically present the interview took place over the telephone. All the other participants were interviewed face-to-face. Because of time restraints the majority of the lawyers only answered the questionnaires and took part in the interviews. However two of the lawyers donated a further period of their time participating in the third method of data collection, being participant observation. These two lawyers were given a series of small computer searching tasks to fulfil, whilst being observed (See Appendix G).

These latter two lawyers were asked to undertake both a factual task finding three specific pieces of information in Brookers Online Library. This library was accessed through the researcher's university account. Brookers Online Library contains a collection of New Zealand legal materials including statutes, regulations and New Zealand bills.

By using this source it makes the task more realistic to how a lawyer would be looking for information in the context of their employment, as in reality they probably wouldn't be searching the wider internet for specific legal information. An audio recorder was used to record their progress. They were asked to think aloud whilst undertaking this task to show what thought processes they are using. This allows their progress to be recorded as and when it happens to see what they are doing. A disadvantage of this is that a recording device is intrusive and they may have been affected by the presence of this, with the result they may have been quieter than normal. 


\subsection{Data Analysis}

Data analysis was used to test the theoretical framework that cognitive, linguistic and socio-behavioural reasons all personal to the user have an influence on obtaining high quality information from electronic resources. In addition the characteristics of computer resources were addressed, such as their relative advantage, compatibility and simplicity.

When the data from the interviews was collected a full, written account of it was made as soon as possible after its collection, whilst it was still fresh in the mind of the researcher. The participant observations were transcribed in the same manner, with the addition of written observations being incorporated, describing non-verbal observations, i.e. long pauses or appearing flustered. All of this data was then recorded in a Microsoft Word document.

Dialogue from the interviews and observations was collected, organised and analysed to show what general themes emerged in relation to each question (See Appendix $\mathrm{H}$ ).

The theoretical framework of Ingwersen and Jàrvelin (2004), together with Rogers (1962) was used to present the themes derived from this research. The themes developed in this research were arranged in the discussion section of this paper under the headings of The Cognitive Approach, The User Orientated Approach and the Diffusion of Innovations theory.

Although this is primarily a qualitative study, a quantitative approach to data analysis was employed in relation to the answers to the questionnaire. This is because these questionnaires contained closed questions, providing a limited choice of answers, e.g. "are you male or female?", or, "how would you rate your computer literacy on a scale of one to five?"

These answers were then analysed by univariate analysis using a frequency table. This provided information showing the percentage of people belonging to each of the categories in question (See Appendix I).

The information provided in these questionnaires was used to show the demographics of the group of lawyers participating in this research. In addition this information was 
incorporated into the discussion section to show patterns that emerged from it, for example that the majority of the older participants are less confident using electronic resources.

\section{Results}

\subsection{Introduction}

The results of this research are presented here. Firstly a description of the participants is given, showing the demographics of the group of lawyers interviewed. Then the results of the semi-structured interviews and the observations are presented, under the headings of the seven interview questions asked.

\subsection{Participant Demographics}

There were nine New Zealand lawyers who participated in this research, five of these participants were male and four were female. They were drawn from three different regions of New Zealand, seven worked in the Auckland Region, one in the Wellington Region and one in the Northland Region of New Zealand.

Their ages ranged between 25 and 64+ with two participants aged 25-29, one aged 3539, two aged 40-44, one aged 45-49, one aged 50-54 and two aged 60-64+. There was a wide range of legal experience between the lawyers with three participants having from 0-4 years, two participants 5-9 years, one participant 10-14 years and three participants $20+$ years of experience. Two of these lawyers worked as in-house lawyers for businesses, and the other seven worked in small to medium sized law firms.

Of these participants, five said that computer technology was available when they undertook their legal training and four said that it wasn't. Three of these participants have undertaken between 1-5 computer training courses and six participants have not undertaken any.

All of the participants said that they used electronic resources to undertake legal research. Two said that a quarter of their research is undertaken using electronic resources, one said half, three said three quarters and three said all. Six participants 
undertook between 0-4 hours of legal research using digital technology per week, two participants between 5-9 hours and one participant between 10-14 hours.

\subsection{Interview Questions}

The responses to the seven main interview questions together with the follow up questions are provided here in order to answer the overriding research question: "What factors influence a lawyer's use of and ability to develop effective electronic information seeking behaviour?"

\section{- What experience do you have of undertaking legal research electronically?}

The theme that background experience is a significant factor influencing a lawyer's use of and ability to develop effective electronic information seeking behaviour emerged from these questions. There was a wide range of experience amongst the nine participants. The responses ranged from three who had had no electronic training and also had no access to legal databases. Their response to being asked how they undertake research was typified in the answer:

"I just Google things and see what comes up really".

Four lawyers had used computers during their university studies but only two of these had undertaken courses on how to use electronic legal resources. One of these had attended a few hour sessions at the library where the librarian had given them some basic training on using the legal databases and the other had had extensive training provided through firstly a second year law paper, followed up by a graded third year paper on the subject.

Although one lawyer had trained prior to the introduction of computers and had attended no computer training courses, he said that he has been using computers regularly both at home and at work since the databases first emerged and was very confident using them:

"I got myself an account with Brookers and just sort of worked out how to use them from there".

The second theme that emerged was whether using electronic legal resources was of advantage to their work. All the participants except one expressed the view that the 
subscription legal electronic resources would either improve their service or had already. Four of the lawyers said that electronic resources were more up-to-date and quicker than hard copy resources:

"Extremely useful, the thing that always concerned me about the print resources is how up-to-date they were, whereas you can rely on the electronic resources to be much more up-to-date...and it makes the job quicker".

The point that there was becoming little choice in whether to adopt electronic technology was raised by two of the participants, who said that hard copy statutes took a long time to be annotated and were in the process of being phased out. The idea that the government is considering the introduction of paperless courts also led some of the lawyers to comment that legal services in New Zealand are becoming far more technologically driven.

However the issue was raised by three lawyers that the subscription databases can be quite complicated to use:

"I found it difficult to work around".

Also the issue was raised by three of the lawyers who didn't have access to the subscription legal databases that they didn't find electronic resources as useful in their daily work because of this:

"I think it is pretty good, it is better if you have access to the databases...It's [Google] hard to get there quickly, it takes time like at the moment I have been trying to find precedents for agreements that we are doing and it's a real challenge trying to do them".

The theme of a lawyer's behaviour toward electronic searching also emerged with these questions. All except one of the lawyers was aware that they could outsource their research to other organisations including the Auckland District Law Society (ADLS). They said that the ADLS service was a quick and efficient service as well as being cheaper than doing it themselves. Yet four of the lawyers said despite these advantages they would still always undertake legal research themselves:

“"We are charging $\$ 220$ an hour and the law library is just $\$ 50$ an hour but I haven't done it before". 
Three lawyers said that they outsource a lot of their research to other legal professionals. Although acknowledging that this is fast and cost effective in the short term one did express the view that it is ultimately of disadvantage to their company, as it meant that she was not up-skilling:

“...which in turn impacts on the company because I'm providing them with advice but to up-skill me more l'd give them better advice".

\section{- What are your views about undertaking legal research electronically?}

When asked about whether obtaining information electronically improved their services the majority of the answers to this were overwhelmingly positive. Comments such as "yes definitely", Yes absolutely" and "Yeah definitely, definitely" were made in response to this question. Five lawyers said that it is quicker and two said it is more up-to-date. The views were expressed that it benefits the client, "keeping the client's bill down" and "time-wise it is good for the client".

Several key themes emerged from these questions. Firstly for several of the lawyers there has to be goals and a purpose to the research. The idea that there had to be a definite advantage to learning how to research was reiterated:

"The less it applies to what you do the less interesting it is".

Six participants said that they found using electronic resources for research easy to adopt and three said that they were very confident using them. One said:

"I use computers as a hobby, I'm always on them".

This raises another theme of the complexity or simplicity of amalgamating electronic research into a lawyer's life. Although six were positive about the ease of use of electronic resources, three participants said that they found it an effort to learn these skills and a lack of knowledge held them back:

“Well I don't know, it would be an effort for me to figure out how to do it, probably knowledge and a training thing".

One lawyer when discussing this issue stated:

"The sooner I retire the better!" 
Three of these lawyers said that they would give up if they could not find the information they required relatively quickly and easily. Two lawyers said that for these reasons it would make them reluctant to undertake electronic research in the first place.

The issue of continuous updates to computer resources was raised by three lawyers as being frustrating and irritating:

"Like any change it takes getting used to".

Two of the lawyer's said that the provider of their subscription legal databases has updated their databases, but they preferred to work with the previous system. One lawyer said that she was not convinced that she could keep up with changes. However four of the lawyers said that these changes were a good thing, as they perceived computer technology to be getting quicker, more efficient and containing better resources.

The theme of time was raised in these questions and recurred throughout the interview, specifically in the question about barriers to the use of digital information. Four participants said that time pressure was a barrier to their undertaking electronic research:

"I think that it takes a hell of a lot of time and wastes a lot of time".

However on the flipside it was considered by several of the lawyers that using the subscription databases made their work quicker and more efficient. Four of the lawyers stated that it made their job quicker and more efficient:

"More up-to-date and sometimes we can get things faster like the legislation website".

Therefore time was a theme of extremes, with approximately half of the lawyers complaining computer research made their work slower and the other half saying that it made their legal services quicker and more efficient.

\section{- How would you describe your cognitive learning process?}

Most of the participants said that they were analytically minded, liking to break problems down into parts and work through systematically. Five of the lawyers said that they like to learn through a combination of visual aids, as well as through direct 
conversation. Seven lawyers said that they like to do work themselves, "I know I can rely on myself", and eight of the lawyers said that they like to use a wide range of resources, "ticked off every possible element that could be relevant". Six participants considered their thinking process as logical although three of these and one other said that they also considered themselves to be intuitive.

These answers give an illustration of the majority of these participants being analytical, logical, visual and verbal, self-reliant and convergent thinkers with a strong element of intuition also coming through.

When asked how they thought their learning style affected their view of using electronic resources their answers reinforced their cognitive processes. One lawyer stated that:

"The way the database is structured now is the way my brain wants to do it".

Five lawyers said that because they learn visually they prefer to have several sources available in front of them at any one time. These could be either hard copy, electronic or a combination. Several of the lawyers said that they like to have more than one computer screen open at once. They said they prefer this because they need to analyse and view several different sources together in order to come to a decision.

These cognitive styles were also apparent through answers given to other interview questions. For example the fact that four of the lawyers expressed the view that they would rather undertake their own research than outsource to the ADLS is indicative of the self-reliance found to be a characteristic of several of these lawyers.

\section{- What are the steps you would take to structure an appropriate search strategy?}

This question focussed on the user orientated approach to information seeking in accordance with Ingwersen and Jàrvelin's theory. All nine lawyers were asked to discuss how they would undertake a search for a specified piece of legal information. Four lawyers gave a structured logical answer, describing steps they would follow that would lead to the case and providing alternative options if they ran into difficulties with this initial search string.

Five lawyers said they did not know how to do this electronically and guessed at options. Of these, three said that they would get other people to do it for them and the 
remaining two did not come up with a logical plan saying "I don't really know". Two of these lawyers made no mention they would even attempt to find it themselves saying "I would actually leave it to one of my staff to find it" and "I'd probably go to the law society".

\section{- What other types of barriers are there to your use of digital information?}

The theme of cost as a barrier to undertaking electronic research featured prominently as seven of the participants said this, although their answers related mainly to the purchase of the subscription legal databases:

"Cost is the big issue. That's right I mentioned about LexisNexis, they have priced themselves off the market."

The theme of the time was again raised here and as discussed before, there were negatives and positives raised to the time issue:

"Everyone complains that it's slow", vs. "It's expensive but compared to the timesaving it's not".

Three of the lawyers talked about connection problems, ranging from internet speed, to cables being cut, to having to undertake a lot of overseas travel and encountering the problems related to this:

“A real hassle to connect because we are very high security ... and you don't get a good connection and it takes ages to log on and then the connection keeps dropping". Future concerns regarding computer technology were also raised by two of the lawyers. One said, "I can see in five years' time videos are going to be really necessary to me, fibre will be necessary, but I'm not at that stage yet". Another lawyer said, "I do worry about our reliance on it. Sometimes the fibrotic cable...has been cut and we can't do settlements, we can't use a computer."

Lack of knowledge was raised as a barrier to undertaking electronic research. Two participants said that they were hindered because they didn't have knowledge of what was out there, "if you don't know what you don't know then you don't know it".

This theme was also raised in other parts of the interview, for example when asked about factors that would improve success in using online information one lawyer said, "I 
think there's probably a lot of stuff on there that I could be using that I don't know about."

- What are your experiences and views on undertaking training in digital literacy skills?

When asked whether they would want to undertake training, five participants were positive about the idea. However despite the desire to attend these courses they did not seem to follow through with them, citing several issues that had held them back from doing so:

"I was going to do some training that they were doing at the law society library but I didn't make it", or, "It's just purely a matter of time".

One lawyer stated that she would only want: "targeted training" otherwise "I would just get irritated".

Cost was raised as an issue again, this time in relation to the price of attending training, "you come back again to again what price am I prepared to pay..."

- Are there any other factors not previously covered in this interview that you think would improve your success in using online resources.

This final question was designed to elicit any further details that I had failed to discover during the six main questions. A few of the themes raised in previous questions were reiterated here in the answers, showing these were issues of particular importance to the lawyers, i.e. cost, lack of access to quality databases and lack of computer knowledge.

One barrier to computer use was raised by two participants, namely that looking at a computer screen for long periods of the day was a strain on their eyes, making them reluctant to spend too long on the computer:

"Just in general get sore eyes just looking at the screen with the glare all day". The issue of dependence on quality computer resources was also raised by one of the non-city lawyers who stated that because of their remoteness they do not have access 
to services such as training courses which are available to lawyers close to major centres:

"Travel is just a no go, we probably use it the same as in the city but we're probably a lot more reliant on it".

\subsection{Participant Observations}

Two lawyers were asked to undertake three specific search tasks under observation, using the specialist legal database, Brookers Online. One participant found the information required with relative ease. When she encountered difficulties she stopped to think about her search string, and went back to previous screens in order to change her search strategy. When asked how she had found undertaking these tasks she said she found the specialist database easy and logical to follow.

The other participant had more difficulties with finding the information. She got flustered and said that:

"I have come to that some random way so if I had to find it again I'd never know what I did..."

When asked her opinion on undertaking these searches she said that she did not enjoy them and would have probably given up:

"I would have told people it was not a good website and it's too hard to use".

\section{DISCUSSION}

The results of this study have demonstrated several key findings regarding the factors that influence a lawyer's use of and ability to develop effective electronic information seeking behaviour. In accordance with Ingwersen and Jàrvelin's theoretical framework for information seeking and retrieval the following themes have emerged.

\subsection{The Impact of Cognitive Features}

- Individual cognitive style impacts on use of electronic resources.

The majority of the lawyers said they considered that their individual cognitive style had an impact on the way that they undertook electronic research and their views on using 
computer resources. These ranged from one lawyer who said that his brain worked in the same way as computers, to three lawyers saying that they prefer working from books, finding it confusing trying to navigate within computer screens. The majority said that they prefer to have several screens or a combination of computer screens and books open at once. This follows with the majority view of the participants that they need to analyse and consult several different sources at once in order to come to a decision. The fact that the majority of lawyers preferred to undertake their own research, despite financially viable alternatives also reflected the self-reliant characteristic of these lawyers.

\section{- Previous training and experience}

The results have shown that previous training and experience directly correlate to confidence and ability. Three of the four users who used computers at university were confident in using electronic resources. One of the four expressed trouble in finding high quality information but this was also related to the fact that she no longer had access to the specialist legal databases.

One of the lawyers who had trained before the introduction of computers was very confident and effective in using these resources, as he spent expensive periods of both his personal and work time using computers and teaching himself how to use them.

\section{- Age of participants}

Age was found to be an important factor as three of the four lawyers over the age of 45 had difficulty with undertaking electronic research, one of whom had access to the specialist legal databases. Four of the five lawyers under the age of 45 were confident with using the legal databases and online searching. However it seems that personality, training and experience also have a significant effect on information seeking behaviour.

\section{- Behaviour toward information retrieval}

Three of the lawyers outsourced a significant amount of their legal research to either other people in their law firms, or to outside services. Two were comfortable doing so, however one disliked this method, saying this was firstly to her detriment and secondly to the detriment of her business, as they were not up-skilling her. Four of the other lawyers knew about the ADLS research service and thought it was efficient and cost 
effective, yet still preferred to undertake research themselves. Three of these four are the same three that had previous training and experience. This shows that despite viable cost efficient alternatives to the point that one applicant said it was significantly cheaper to outsource research, participants who are confident in this area are more likely to want to undertake legal research themselves.

\section{- Goals and purpose}

Seven of the nine participants said that they had learnt how to use computers by playing around with them. One said that he was always on them. However two expressed that their needs to be a definite advantage to them in learning how to undertake further research and they would be frustrated with learning just for the sake of it.

\section{- Emotions and Expectations}

This theme was closely tied into the theme of the complexity or simplicity of taking up computer technologies raised under Rogers' framework. There was a direct correlation between the lawyers who found electronic resources easy to use and those that enjoyed using them. The participants who were positive about using them in their work also said that they found them easy to pick up and use, whereas the three that expressed negative emotions about undertaking electronic legal research said that they found it an effort to learn about and they lacked sufficient knowledge.

\section{- Lack of knowledge}

Three lawyers stated that there is probably a lot of information available to them through electronic resources that would be useful, yet a lack of knowledge of what is available holds them back from obtaining quality information.

\section{- Learning through Training}

Despite the fact that five participants were positive about the prospect of undertaking training, six of the participants had not undertaken any computer training at all. There were a myriad of reasons given for why they did not attend training courses, from lack of time, cost, never actually getting there, to finding it frustrating unless it is specifically tailored to their needs. This leads to the conclusion that despite in theory most of the participants being open to the idea of learning through training, the everyday realities of 
life mean that in practise this doesn't happen. Consequently they are learning the majority of their electronic research skills through trial and error.

\subsection{The User-orientated approach.}

\section{- Hypothetical search request}

Here the way lawyers would undertake a search for a new piece of legal information was analysed by asking them how they would find information in a hypothetical search request. Four of the lawyers found this an easy task to undertake, giving a structured, logical answer. All three of the lawyers who had expressed negative emotions towards undertaking electronic legal research said that they would not undertake a task like this and would get another person to undertake it on their behalf. The remaining two lawyers who said that they did not know how they would undertake this task were lawyers who said that they found computers easy to use. However both of these lawyers were two of the five that had no access to the specialist legal databases at work, which indicates that without these databases it can be very difficult to find the information you require, despite being computer savvy. However one of the four that gave a structured, logical answer was the lawyer who said he spent a significant part of his life using computers, showing that sufficient knowledge of computers is a big advantage and can overcome the disadvantage of lack of access to the subscription websites.

\section{- Participant Observation}

Two lawyers were asked to undertake three specific search tasks under observation, using the specialist legal database, Brookers Online. Although they were both lawyers who trained before computers were integrated into university study and they were both lawyers who had no access to the specialist legal databases in their everyday work, the one who was more successful was also one of the lawyers who said that she was confident using computers. Whilst she had struggled with describing how to find information in the theoretical search above, when she was provided with access to specialist databases she was able to follow a logical process that lead her to the information. 


\section{- Results}

The results of this hypothetical question and real-life observation suggest that:

- $\quad$ Those that are computer savvy and have access to high quality legal databases showed confidence and skill in undertaking legal research.

- Those that are highly skilled in using computers can overcome barriers of lack of access to specialist databases to find the information that they need.

- Those who have some confidence and skill in using computers but do not have access to the specialist databases do better than those who have less computer skills and no access to these databases.

\subsection{Rogers' Diffusion of Innovations Theory.}

- Relative Advantage (how using electronic resources will improve the current situation)

The advantage of using electronic resources was significantly tied into access to the electronic databases. Of the five that don't have access to these databases three said that they did not find computer resources an advantage to them at all in their work.

All of the participants except for one said that the subscription legal databases would improve their legal services. However this advantage is directly linked to the disadvantage of cost as seven of the participants said that cost was a barrier to using these databases with the result that five lawyers do not have access to these.

Four of the lawyers stated that electronic resources are more up-to-date than hard copy resources and also spoke of the financial advantage to the client, as using electronic resources is far more time effective.

Two of the lawyers with negative views towards using electronic resources, still expressed the view that computers were becoming a necessity in the workplace. They said that paper statutes are taking a long time to be updated and are in the process of being phased out. Two lawyers referred to the government's vision of 'paperless 
courts'. Therefore it was considered that it was becoming more and more difficult to avoid using electronic resources.

- Compatibility: (How easy to assimilate this innovation into the user's life).

\section{Lack of Access}

For the lawyers without access to the subscription databases, most struggled to find quality legal information through electronic resources. Three of these lawyers said it was not through their own choice that they did not have this access as decisions were made on purchasing these by more senior members of their workplace.

The technological barrier of lack of access was also raised by three lawyers. These barriers ranged from cables being cut, to slow connection speeds to difficulties accessing electronic information whilst travelling overseas for their work.

Two lawyers spoke of their concerns that lawyers are becoming very dependent on electronic resources for their work. One lawyer raised the possibility that in the future additional electronic resources will be required as computers become more and more integrated into the legal workplace, for example video conferencing equipment and faster connections may be required.

\section{Cost}

Cost has already been raised in this discussion and it is a major theme as it is interrelated with several of the other themes. Cost was mainly considered a barrier in relation to the purchase of the legal subscription databases. However it was raised in a positive light also by some of the lawyers who did use these subscription databases, saying that because they had current, up-to-date information available immediately to them, this meant that they spent less time researching information and they were able to keep client's costs down.

\section{Time}

Time was a theme of extremes, with approximately half of the lawyers complaining computer research made their work slower and the other half saying that it made their legal services quicker and more efficient. 
Four lawyers rose time saved as a positive factor for using electronic resources saying that work is undertaken more quickly and efficiently. However four participants talked about time pressure being a barrier to them undertaking electronic research. This can be explained by the fact that the majority of those with access to the subscription databases seemed to find undertaking research fast and efficient whilst the majority of those without this access struggled to undertake research electronically.

\section{Physical Issues}

Two of the lawyers raised the issue that looking at a computer screen all day can cause sore eyes. This meant that for both of them they limited the amount of screen time they had because of this. This shows that there can be physical barriers personal to the user making it difficult for them to use online legal resources.

\subsection{Findings of this research compared to previous studies}

This study reiterates Davis's findings using his (1989) technology acceptance model, (TAM) where he theorised that ease of use and usefulness are the key determinants of whether a user will adopt technology. In this current study ease of use through access to the subscription databases was a key determinant in whether users were able to undertake effective electronic research. Computer resources were considered highly important by all, even those who disliked using them, with the view expressed that many legal services were heading towards a computer based approach. Only one lawyer without access to these databases found it easy to find the information he required electronically.

Shih \& Venkatesh (2004) found that the uptake of technology is influenced by an individual's propensity to adopt technology as well as the perceived essentialness of it. This finding is reiterated in this study. The lawyers who were the most immersed in electronic resources also embraced them with a positive attitude and considered them to have integral benefits to their businesses. Although all the lawyers considered these resources very important and the way of the future for law, not all were prepared to take them up.

In Chawner's (2008) study she found that age was a significant factor in determining how many different computer technologies a person used regularly. In this current 
study three of the four lawyers over the age of 45 had difficulty undertaking electronic research, one of whom had access to the specialist legal databases.

All except one of the lawyers under 45 years of age had had access to computers during their university study and so had been using them for legal research from the outset. However the fact that one of the lawyers over 45 years was completely immersed and proficient in their use shows that whilst age is important, it is one of a number of contributing factors to whether lawyers undertake effective electronic research.

In accordance with the findings of Hollis, Sawyer and Sterns (1999) one of the lawyers over 45 years who had difficulty with electronic research said that when he was shown how to undertake goal specific tasks he found these easy to understand and undertake, indicating lack of awareness of how to undertake these tasks rather than lack of ability to do so had held him back.

Like Chawner (2008) found, institutional barriers played a major role in this current study as to whether electronic research was undertaken. Lack of access to the specialist websites was cited by all except one of the lawyers without them, as a major reason why they struggled to obtain the information they required electronically. Cost was the overriding factor as to why these databases were not used, and three lawyers expressed frustration that they had no say in what, if any databases they were provided with, as these decisions were made by more senior members in their work places. In accordance with Eveland (1986) the decision whether to have access to these resources was generally not based on the quality of these resources, rather the issue of cost.

The lawyers who had access to the specialist databases were given the option of receiving training in how to use these from the companies providing them. Of the five lawyers who did not have access to these databases only one said he found it easy to find the electronic information he required. This indicates that it is important for these lawyers without access to specialist databases to undertake training.

The results of this study agree with Jacobson and Fusani (1992) that it is search experience and database knowledge rather than legal knowledge that are the key elements in obtaining the required information electronically. The majority of the lawyers who were the most confident and proficient at finding information electronically were the ones who trained at the time when computers were available, 
whereas the majority of the lawyers who studied before computers were available struggled with using electronic resources effectively.

This study differed from the study of Debowski (2001) which found that law students did not develop effective search techniques when left to their own devices, focussing on inputting the data and not thinking through search strategies. In this current study four of the nine lawyers outlined effective and detailed strategies when asked to discuss how they would approach undertaking a search for a specified piece of legal information. Although another said that she did not know how she would undertake this task, when she later undertook one of the practical observations she was also able to construct a successful search strategy.

The reason for this difference is likely to be because the majority of lawyers in this study have been using computers regularly in their workplaces and have practical experience searching for information, developed over a period of time. Poynton (2005) states that whilst training is important, practise is the biggest positive factor in acquiring good quality searching skills, which is found to be the case in this current research.

Only one of the participants in this current study had learnt their electronic research skills through extensive training, compared to all the others who said that they had mainly taught themselves through trial and error. Training was said to be important by the majority of the lawyers. However the issue appears to be how to actually get lawyers to undertake training. Nearly all the lawyers had undertaken either none, or very few training courses. This agrees with Price in that training has to be tailored to the individual and be seen as relevant to them, otherwise it won't happen.

\section{Conclusion and Recommendations}

\subsection{Conclusion}

In order for lawyers in New Zealand to develop effective information seeking behaviour it is necessary to understand the cognitive and user-orientated reasons why lawyers do or do not look for information effectively from this source. Whilst there have been studies undertaken previously on the searching techniques of lawyers in New Zealand, there have been no previous studies undertaken in New Zealand about these reasons 
why lawyers may choose not to use electronic resources. This study looks in detail at the ways lawyers in New Zealand use and feel about the electronic information searching environment.

By using a phenomenological study design it allows this study to explain the viewpoint of the lawyers first hand regarding their use of, and attitudes towards using electronic resources. Through the nine interviews undertaken the lawyers discussed in detail the cognitive, linguistic and socio-behavioural reasons why they do or do not use electronic resources as well as other reasons, external to the lawyers influencing their use of them. These interviews were then built on through two participant observations where the researcher was able to observe first-hand how two lawyers interacted with the electronic resources.

A wide demographic sample of New Zealand lawyers was used for this study. There were similar numbers of men and women, a spread across most age groups and experience levels and the nine lawyers came from three different regions of the North Island. In addition their workplaces ranged from in-house lawyers, small law firms and medium sized law firms. This diversity makes the study relevant to several different sectors of the New Zealand legal community.

The lawyer's responses to the interview questions were in accordance with Ingwersen and Jàrvelin's (2005) theoretical framework showing why and how lawyers learn electronic information seeking skills and the physical and cognitive reasons hindering their development of these skills. Several of the issues they raise as having an impact on learning were found to be relevant to this study.

Training, electronic experience, personality and age were all shown to have a significant effect on information seeking behaviour. It was also found that it was mainly the senior members of work places making the decisions on what specialist legal resources are used by their firm. In most cases these are the older members in a law firm and the most experienced in law. Yet it is often the younger lawyers who trained after the introduction of computers who have the most knowledge and experience of what electronic resources are the best and how these will be beneficial in their workplaces.

Although most of the lawyers knew about the legal research services available to them through organisations such as the ADLS, the majority of the lawyers still preferred to 
undertake electronic research themselves, despite the fact it was said by several that outsourcing was financially cheaper.

The lawyer's behaviour towards undertaking electronic searching shows for the majority there is an enthusiasm and a drive about how to learn these skills. In accordance with their cognitive styles, most of them want to do this for themselves, staying in control of the research process, and therefore law firms need to harness this enthusiasm and create a learning environment where the lawyers can up-skill.

Knowledge of computer resources available was considered to be a key factor and it was expressed by some participants that there must be a lot of information available to lawyers electronically that would be useful and they would like to learn about. The majority of the lawyers were positive about attending training courses, yet only one third had done so. Several of the lawyers expressed the views that training courses were too time consuming, or simply not tailored to their level of computer ability or their specific information requirements. Some of the participants expressed the view that they would be happy to undertake training courses that overcame these concerns.

In addition the issue of keeping up-to-date with changing computer technologies was raised by several participants as an on-going concern. Even some lawyers who were confident in using electronic resources expressed doubts that they would be able to keep up with changes. There is a need for lawyers to have access to refresher training courses to keep on top of these changes.

The study results also adhered to Rogers' (1962) Diffusion of Innovations theory as this theory focusses on how and why new technology is used by a culture, in this case lawyers.

The advantages of having current, high quality information available to them via electronic resources was considered very important by the majority of the lawyers, who saw a flow on time and cost saving benefit for their clients. Yet time was also raised as a significant barrier to undertaking electronic research by several of the lawyers. This contradiction is due to knowledge and access. The majority of the lawyers who knew where to go for information and had ready access to the specialist databases or other relevant websites found it quick, easy and time saving, whereas the ones with less electronic experience and knowledge generally found it took a lot of extra time. 
Where there is more than one lawyer in the workplace the problems with time and knowledge could be mitigated if the law firms nominated a computer savvy lawyer to oversee the firm's computer resources and training. This means that rather than several lawyers spending time looking for resources, one is doing so and sharing their results with everyone. This can save time, and therefore cost. This could be particularly beneficial for the law firms that do not have access to the specialist databases.

Whilst a few technological barriers to access of electronic information were raised, such as connection speed and outages the main issue raised in this area was the lack of access to specialist legal databases. The majority of the lawyers said that access to these databases was an advantage to their work. Lack of access was mainly due to the cost of acquiring these resources. Lack of access affected the lawyer's ability to be able to easily obtain up-to-date, reliable information. It is a major issue for many lawyers, particularly in sole or small law firms, that they do not have the electronic information available to them to undertake research effectively.

Finally simple changes can be made to make undertaking electronic research for lawyers more pleasurable. Eye strain through looking at a computer screen for hours on end was raised as in issue.

\subsection{Recommendations.}

- Rather than decisions on what electronic resources to subscribe to being made by the partners or senior members of a work place, giving the lawyers who are the most experiences and trained in using these resources a say in what electronic resources, if any, to subscribe to would be beneficial to a workplace.

- Most lawyers are open to undertaking training but the reality of trying to fit this into their busy work lives means that it doesn't happen. In accordance with Eells (2008), providing lawyers with online training courses that they can undertake at a time that suits them in their own office may mean that they are more likely to do so.

- The importance of having courses tailored to their level of computer expertise, and specific to areas that are relevant to them was a major factor for several lawyers in undertaking them. The courses need to be introduced with enough detail so that 
lawyers know exactly what they are getting involved in before they spend money on undertaking training.

- Even though age and background experience were found to be contributing factors to undertaking electronic research, this study has shown that cognitive style is also a major factor in learning new skills, with several of the more senior lawyers saying that they would be open to learning electronic skills. Providing services tailored to addressing their needs and level of ability is important.

- As the issue of continuous updates was raised as an issue by several lawyers, making sure that lawyers have the option to attend refresher training courses is important to keep them up-to-date.

- The advantages of using high quality electronic resources was raised as very important to law firms as it was seen to provide clients with a faster more efficient service. Therefore allocating one computer proficient member of staff the role of ensuring that members of that workplace are obtaining the legal resources and training that they require would mean that the business is obtaining the maximum benefit from these resources.

- In particular for the lawyers who don't have access to the specialist legal databases constructing a list of relevant resources would be useful. This could be provided by the staff member overseeing the computer proficiency of the lawyers. This means that rather than several lawyers spending time looking for resources, one is doing so and sharing their results with everyone. This can save time, and therefore cost.

- Although you can tailor the products you purchase through the specialist databases, cost was raised as a major factor by several participants. It appears that many lawyers are not getting access to legal information that is very important to them because of this. Options could be explored to see if there are any viable alternative methods to access these databases.

- There are additional functions available through a computer that many lawyers may not be aware of. For example there are functions on a computer to aide users with visual 
impairments. Familiarising members of a workplace with these tools may make their physical interactions with the computer more enjoyable.

\subsection{Areas warranting further study}

This study has looked at the factors influencing the use of online research resources by lawyers. It has been shown in this study that people have different information needs and ways of learning. A trainer needs to understand a user's needs and requirements, otherwise they are unlikely to engage with the process. Further study needs to look at strategies and training methods required by lawyers and their employers to improve these skills. For example online training courses have been discussed as a viable method to get lawyers to undertake training. Finding suitable courses or developing methods and teaching aides for providing these courses are necessary.

Using a phenomenological study design has meant this research has been able to take an in-depth look at this issue using a small number of participants. However a future study could focus on a wider scale survey of lawyers in New Zealand using a quantitative approach. The themes identified in this current research could provide the basis for the questions asked. By using a larger population sample it could show how widespread the issues identified here are amongst New Zealand lawyers.

In addition only two participant observations were carried out in this current study. Undertaking further qualitative research involving a larger sample of lawyers for participant observation would provide more valuable, in-depth data. 


\section{References}

Bryman, A. (2008). Social Research Methods ( $3^{\text {rd }}$ ed.). Oxford: Oxford University Press.

Chawner, B. (2008). Spectators, not players: information managers' use of Web 2.0 in New Zealand. The Electronic Library, 26(5), 630-649. Doi:

10.1108/02640470810910666

Childers, S. (2003). Computer literacy: necessity or buzzword? Information Technology and Libraries, 22(3), 100-106.

Cochran, N. (1980). Society as emergent and more than rational: an essay on the inappropriateness of program evaluation. Policy Sciences 12(2), 113-129.

Davis, F. D. (1989). Perceived usefulness, perceived ease of use, and user acceptance of information technology. MIS Quarterly, 13(3), 319-340.

Debowski, S. (2001). Wrong way: Go back! An exploration of novice search behaviours while conducting an information search. The Electronic Library, 19(6), 371-383. Doi: 10.1108/02640470110411991

Eells, L.L. \& Jaguszewski, J.M. (2008). IT competence for all: propel your staff to new heights, Technical services quarterly 25(4), 17-3.

DOI:10.1080/07317130802128015

Eveland, J.D. (1986). Diffusion, Technology Transfer, and Implementation: Thinking and Talking About Change. Science Communication, 8, 303. Doi: $10.1177 / 107554708600800214$

Finlay, L. (2009). Debating phenomenological research methods", Phenomenology \& Practice,(3), 6-25. 
Goad, T. (2002). Information literacy and workplace performance ( $1^{\text {st }}$ ed.). Westport, CT: Quorum Books.

Harris, Paul. 2005. Online Assessment Tools Fill Learning's Gaps. TD, 59(6), 62-63.

Hollis-Sawyer, L.A. \& Sterns, H.L. (1999). A novel goal-oriented approach for training older adult computer novices: Beyond the effects of individual-difference factors. Educational Gerontology, 25(7), 661-684.

Husserl, E. (1936). Crisis of European Sciences and Transcendental Phenomenology. Evanston, IL: Northwestern University Press.

Jacobson, T \& Fusani, T. (1992). Computer, System, and Subject Knowledge in Novice Searching of a Full-Text, Multifile Database. Library and Information Science Research, 14, 97-106.

Jennings, A. (2005). Determining and Meeting Personnel Training Needs: after computer proficiency was tied to salaries and promotions, staff tech training took on a whole new urgency. Computers in Libraries, 25(8), 13-15.

Ingwersen, P. (1992). Information Retrieval Interaction. London: Taylor Graham. Retrieved 25 August 2013 from http://pure.iva.dk/ws/files/31047349/Ingwersen_IRI.pdf

Ingwersen, P. \& Jàrvelin, K (2005). The turn: Integration of information seeking and retrieval in context. Dordrecht: Springer.

McKechnie, S., Winklhofer, H. \& Ennew, C. (2006). Applying the technology acceptance model to the online retailing of financial services. International Journal of Retail \& Distribution Management, 34(4/5), $388-410$. doi10.1108/09590550610660297\#sthash.Q7QmEzrm.dpu

Monsuwe, T.P., Dellaert, B.G.C., de Ruyter, K.R. (2004). What drives consumers to shop online? A literature review. International Journal Services Industry Management, 15(1), $102-121$. Retrieved from http://arno.unimaas.nl/show.cgi?fid=2720\&origin=publication_detail 
Mozenter, F., Sanders, B.T \& Bellamy, C. (2003). Cross-training public service staff in the electronic age: I have to learn to do what?! Journal of Academic Librarianship, 29(6), 399-404.

Palmquist, R.A. \& Kim, K. (2000). Cognitive style and on-line database search experience as predictors of Web search performance. Journal of the American Society for Information Science, 51(6), 558-566.

Patsiotis, A.G., Hughes, T., Webber, D. J. (2013). An examination of consumers' resistance to computer-based technologies, Journal of Services Marketing, 27(4), $294-311$.

Patton, M.Q. (1990). Qualitative Evaluation and Research Methods ( $3^{\text {rd }}$ ed.). Newbury Park, CA: Sage.

Pearson, G.R. (2008). An Exploration of the Database Search Behaviour of Law Librarians and Lawyers. Wellington, New Zealand: Unpublished. Retrieved from http://hdl.handle.net/123456789/1721

Poynton, T.A. (2005). Computer literacy: A review with implications for educators. Computers in Human Behavior, 21(6), 861-872. doi: 10.1016/j.chb.2004.03.004

Price, K. (2006). Training offers a Passport to IT success. I T Training (Dec2006), 9.

Robinson, K. M. (1997). How lawyers search when no one is looking: A transaction log analysis study to evaluate the educational needs of the legal profession. New Zealand Law Librarian, 3 (3 \& 4), 86-109.

Rogers, E. M. (1962). Diffusion of innovations. New York: Free Press. 
Shih, C-F. \& Venkatesh, A. (2004). Beyond Adoption: Development and Application of a Use-Diffusion Model. The Journal of Marketing, 68(1), $59-72$.

Wood, S.L., \& Moreau, C.P. (2006). From Fear to Loathing? How Emotion Influences the Evaluation and Early Use of innovations. Journal of Marketing, 70(3), 44-57. 
TE KURA TIAKI, WHAKAWHITI KŌRERO

LEVEL 5, RUTHERFORD HOUSE, PIPITEA CAMPUS, 23 LAMBTON QUAY, WELLINGTON

PO Box 600, Wellington 6140, New Zealand

Dear

I am currently undertaking study towards a Master of Information Studies degree through Victoria University of Wellington. I am required to undertake a research study as part of this degree. Having previously worked as a lawyer I am very interested in the use of online legal research services by lawyers. This study intends to examine the factors that have an influence on a lawyer's use of these services.

The title of this study is:

\section{The factors influencing the use of online legal research services by} lawyers.

With the advances in technology, obtaining information from electronic resources requires users to develop a whole new set of skills. This research looks at how an individual's cognitive and personal 
characteristics are involved in influencing a lawyer's use of online legal information sources. It also looks at institutional barriers to the use of these resources, for example the cost of accessing subscription websites. Finally it looks at lawyer's views and attitudes towards being trained in the use of electronic legal resources.

I would like to ask your permission to interview you for this research project. This interview will last approximately 30 minutes. At the beginning of the interview you will be asked to complete a short questionnaire about your background. Alternatively, if you are undertaking the interview by telephone, this questionnaire will be emailed to you prior to the interview. You and your law firm will not be identified in the final report or any publication resulting from this research.

My research supervisor for this study is Dr Brenda Chawner at the School of Information Management, VUW. Her contact details are:

Email: $\quad$ brenda.chawner@vuw.ac.nz

Telephone: 044635780

Please do not hesitate to contact either myself of Dr Chawner should you need any further information.

Regards

Geraldine Lewis 
computer training. It could also be institutional barriers such as the cost of obtaining these electronic resources or computer security issues. This research investigates how an individual's past and present experiences as well as their social, organisational and cultural environment impact on the whole process. This knowledge can then be used in order to develop strategies and training programmes to address any issues with computer literacy or information retrieval that may arise out of the information provided. Victoria University requires, and has granted, approval from the School's Human Ethics Committee.

I am inviting a range of lawyers to participate in this research. Both men and women will be selected and whilst most of the lawyers will be recruited from Auckland, there will be a few lawyers invited to participate from different regions of New Zealand. These lawyers are intended to be drawn from a variety of workplaces, ranging from working for companies as in-house lawyers, to selfemployed, or working for a law firm. Participants will be asked to take part in a half hour interview. This will take place either face-to-face or by telephone, where participants are unable to attend in person. Permission will be asked to record the interview, and a transcript of the interview will be sent to participants for checking.

At the beginning of the interview you will be asked to complete a short questionnaire about your background which will take a couple of minutes. Alternatively, if you are undertaking the interview by telephone, this questionnaire will be emailed to you prior to the interview. 
A further participant observation will also be undertaken on a small subsection of these participants, where they will be observed undertaking a factual information search task. This will take place in person and take approximately a further half hour.

Participation is voluntary, and you will not be identified personally in any written report produced as a result of this research including possible publication in academic conferences and journals. All material collected will be kept confidential, and will be viewed only by myself and my supervisor $\mathrm{Dr}$ Brenda Chawner, IST Programmes Director, School of Information Management. The research report will be submitted for marking to the School of Information Management, and subsequently deposited in the University Library. Should any participant wish to withdraw from the project, they may do so until $11^{\text {th }}$ December 2013 and the data collected up to that point will be destroyed. All data collected from participants will be destroyed within 2 years after the completion of the project.

If you have any questions or would like to receive further information about the project, please contact me at lewisgera@myvuw.ac.nz or telephone 09 8176546 or you may contact my supervisor Dr Brenda Chawner at brenda.chawner@vuw.ac.nz or telephone 04 463-5780.

Geraldine Lewis 


\section{Appendix C: Consent Form}

TE KURA TIAKI, WHAKAWHITI KŌRERO

LEVEL 5, RUTHERFORD HOUSE, PIPITEA CAMPUS, 23 LAMBTON QUAY, WELLINGTON

PO Box 600, Wellington 6140, New Zealand

Phone + 64-4-463 5103 Fax +64-4-463 5446 Email sim@vuw.ac.nz Website www.victoria.ac.nz/sim

\section{Participant Consent Form}

Research Project Title: The factors influencing the use of online legal research services by lawyers.

\section{Researcher: Geraldine Lewis, School of Information Management, Victoria}

\section{University of Wellington}

I have been given and have understood an explanation of this research project.

I have had an opportunity to ask questions and have them answered to my satisfaction.

I understand that I may withdraw myself (or any information I have provided) from this project, without having to give reasons, by e-mailing lewisgera@myvuw.ac.nz by the $18^{\text {th }}$ December 2013 when data analysis has begun. 
I understand that any information I provide will be kept confidential to the researcher and their supervisor, the published results will not use my name, and that no opinions will be attributed to me in any way that will identify me.

I understand that the data I provide will not be used for any other purpose or released to others.

I understand that, if this interview is audio recorded, the recording and transcripts of the interviews will be erased within 2 years after the conclusion of the project. Furthermore, I will have an opportunity to check the transcripts of the interview.

Please indicate (by ticking the boxes below) which of the following apply:

I would like to receive a summary of the results of this research when it is completed.

I agree to this interview being audio recorded.

Signed:

Name of participant:

Date: 
Appendix D: Questionnaire

\section{Questionnaire}

(Where multiple options please circle correct one)

Name

Law firm

$\begin{array}{llllllllll}\text { Age } & 20-24 & 25-29 & 30-34 & 35-39 & 40-44 & 45-49 & 50-54 & 55-59 & 60-64\end{array}$

Sex: $M \quad F$

$\begin{array}{llllll}\text { Years of legal experience } \quad \text { Law Student } & 0-4 & 5-9 & 10-14 & 15-19\end{array}$

20 or over

Was computer technology available to you when you undertook your formal legal training?

Yes No

$\begin{array}{llll}\text { Computer training courses undertaken } & 0 & 1-5 & <5\end{array}$

Approximately how many hours a week would you undertake legal research using digital technology?

0-4 5-9 10-14 15-19 20 or over

Approximately what proportion of your research is undertaken using electronic resources?

$\begin{array}{lllll}0 & 1 / 4 & 1 / 2 & 3 / 4 & \text { All }\end{array}$ 


\section{Appendix E: Semi-structured Interview}

\section{Semi-structured Interview}

1 Previous experience: What experience do you have of undertaking legal research electronically?

2 The motivational and emotional side of information seeking: What are your views about undertaking legal research electronically?

3 The cognitive side of information seeking: How would you describe your cognitive learning process? i.e. Are you someone who likes to structure and analyse data to work out solutions or do you like to take more of an observer role.

$4 \quad$ The user-orientated approach: Can you talk me through the steps you would take to go about structuring an appropriate search strategy if you were looking for the original judgement in the family law High Court case: re Estate of Butler.

5 Barriers: What types of institutional barriers are there to your use of digital information? i.e. cost of subscription websites.

6 Training: What types of training have you previously received in searching for electronic information?

7 Other factors: Are there any other factors not previously covered in this interview that you think would improve your success in using online resources? 


\section{Appendix F: Interview Follow-up Questions}

\section{Interview Follow-up Questions}

\section{Previous experience:}

1.1 Do you personally undertake computer research at all? If no, please go to question 1.5 .

1.2 How useful do you think it is as a source for the legal information you require?

1.3 What websites and databases do you use to look for this information?

1.4 Do you feel that previous experience in using electronic resources helps you undertaking new challenges, and if so, how does it help?

1.5 If you don't undertake computer research, have you done so previously? What was the outcome of this?

1.6 Do you employ someone to undertake electronic research for you? What do you think are the advantages and disadvantages of doing so?

2. The motivational and emotional side of information seeking:

2.1 How do you feel about learning any new skill at all, not just digital information literacy skills?

2.2 What feelings do using computer resources evoke in you? I.e. fear, embarrassment of failing, anxiety?

2.3 Would negative emotions such as anxiety to the process make you inclined to give up more easily and if so why?

2.4 How do you feel about the fact computer technology is constantly changing and requiring you to use new innovations? I.e. using apps or new databases.

2.5 What are your views on whether learning these skills is actually necessary? How do you think obtaining information electronically improves your service you provide, if at all? 
3.1 How would you describe your cognitive learning process? Are you someone who likes to structure and analyse data to work out solutions or do you like to take more of an observer role.

3.2 Do you think that your learning style affects your view on using electronic resources and if so how?

3.3 If it affects it negatively what factors do you think could mitigate this? I.e. training, practise.

4 The user-orientated approach

Can you talk me through the steps you would take to go about structuring an appropriate search strategy if you were looking for the original judgement in the family law High Court case: re Estate of Butler.

$5 \quad$ Barriers

5.1 What types of barriers are there to your use of digital information?

5.2 Are there any organisational or technological barriers that influence your use of electronic resources?

6 Training in digital information literacy skills:

6.1 What types of training have you previously received in digital literacy? i.e. formal or informal, online etc.

6.2 If you have received no training, how have you learnt to find the information you require?

6.3 Would undertaking training or alternatively further training in this area have an impact on your attitudes to using electronic resources?

7 Other factors: What other factors do you think would improve your success in using online resources? 


\section{Appendix G: $\quad$ Participant Observation Tasks}

\section{Participant observation: Factual Information Search Task}

You have been asked to find the following information sources for your employer:

1 The orders made by Chairperson Haines in the case Director of Human Rights Proceedings v Sensible Sentencing Trust.

2 An article by Jessica Palmer, Lecturer in Law, University of Otago, titled Understanding the Director's Fiduciary Obligation (2006).

3 The section of the Corrections Act 2004 that relates to the misuse of drugs. 


\section{Appendix H: Analysis of Themes Sample}

\begin{tabular}{|c|c|c|c|c|c|c|c|c|c|c|c|}
\hline Question & A & B & c & D & E & $\mathrm{F}$ & G & H & I & Summary & Codes and Themes \\
\hline $\begin{array}{l}\text { What experience } \\
\text { do you have of } \\
\text { undertaking } \\
\text { research } \\
\text { electronically? }\end{array}$ & $\begin{array}{l}\text { A little bit } \\
\text { using } \\
\text { LexisNexis (LN) } \\
\text { but I don't use } \\
\text { it at work so I } \\
\text { don't use it } \\
\text { regularly...its } \\
\text { kind of like you } \\
\text { have to start } \\
\text { from scratch } \\
\text { because if } \\
\text { you're out of } \\
\text { uni you learn } \\
\text { as you go }\end{array}$ & $\begin{array}{l}\text { Well all } \\
\text { through } \\
\text { university I } \\
\text { was using } \\
\text { computers as } \\
\text { well as print } \\
\text { resources. } \\
\text { Yeah we had a } \\
\text { computer lab } \\
\text { in the library } \\
\text { where we had } \\
\text { Brookers and } \\
\text { LN on the } \\
\text { computers } \\
\text { I'm lazy Im a } \\
\text { lazy researcher } \\
\text { and if I can sit } \\
\text { infront of a } \\
\text { computer and } \\
\text { getall of the } \\
\text { info fed to me } \\
\text { that suits me } \\
\text { much better } \\
\text { than getting } \\
\text { off my bum } \\
\text { and going and } \\
\text { finding a book. }\end{array}$ & $\begin{array}{l}\text { Well I've } \\
\text { done it since } \\
\text { I've been in } \\
\text { practise and } \\
\text { I've been in } \\
\text { practise for } \\
\text { about } 10 \% \text { \%/ } \\
\text { years now } \\
\text { and right from } \\
\text { the outset we } \\
\text { would do our } \\
\text { research, well } \\
\text { I w would do it } \\
\text { electronically } \\
\text { at least not } \\
\text { my senior } \\
\text { partner } \\
\text { whose a bit } \\
\text { older a bit } \\
\text { behind the } \\
\text { times but } \\
\text { yeah Ive } \\
\text { always done } \\
\text { it } \\
\text { electronically, } \\
\text { right from the } \\
\text { outset. } \\
\text { I used to use } \\
\text { LN when I } \\
\text { was at } \\
\text { university but } \\
\text { I don't use it } \\
\text { in our firm } \\
\text { because }\end{array}$ & $\begin{array}{l}\text { Just practical } \\
\text { experience } \\
\text { ever since the } \\
\text { databases first } \\
\text { emerged. I got } \\
\text { myself an } \\
\text { account with } \\
\text { brookers and } \\
\text { just sort of } \\
\text { worked out } \\
\text { how to use } \\
\text { them from } \\
\text { there. } \\
\text { I'm the } \\
\text { generation } \\
\text { that graduated } \\
\text { before the } \\
\text { technological } \\
\text { wave } \\
\text { happened but } \\
\text { I've tried to } \\
\text { pick it up as } \\
\text { quickly as I } \\
\text { could, I'm } \\
\text { surrounded by } \\
\text { the bloody } \\
\text { things.Picked it } \\
\text { up myself } \\
\text { basically, set } \\
\text { up in sole } \\
\text { practise in } \\
\text { 1988 bought } \\
\text { myself a really } \\
\text { old xt }\end{array}$ & $\begin{array}{l}\text { Minimal but } \\
\text { that's by my } \\
\text { choice because } \\
\text { I didn't have } \\
\text { computers } \\
\text { when I went } \\
\text { into the } \\
\text { business I'm } \\
\text { used to paper } \\
\text { resources. }\end{array}$ & $\begin{array}{l}\text { I suppose } \\
\text { through my } \\
\text { studies was } \\
\text { when I was } \\
\text { doing the most } \\
\text { research and in } \\
\text { my previous job } \\
\text { I was doing } \\
\text { more and we } \\
\text { had a course at } \\
\text { university and } \\
\text { the law } \\
\text { librarians } \\
\text { taught us how } \\
\text { to use Brookers } \\
\text { and LN and } \\
\text { things like that. }\end{array}$ & $\begin{array}{l}\text {..in Stage } 3 \\
\text {.Auckland..., } \\
\text { they put a lot } \\
\text { of emphasis } \\
\text { on research... } \\
\text { So you actually } \\
\text { got a } \\
\text { grade... on } \\
\text { doing } \\
\text { electronic } \\
\text { research... } \\
\text { One semester } \\
\text { and the whole } \\
\text { point was I } \\
\text { would say that } \\
\text { about } 70-80 \% \\
\text { was all online } \\
\text { stuff so you } \\
\text { got used to } \\
\text { online } \\
\text { databases... }\end{array}$ & $\begin{array}{l}\text { Well } \\
\text { probably I go } \\
\text { onto the NZ } \\
\text { leg website } \\
\text { and I look up } \\
\text { Y an act or } \\
\text { regulation...I' } \\
\text { ve got it } \\
\text { saved on my } \\
\text { computer as } \\
\text { a favourite so } \\
\text { that I can go } \\
\text { to it quite } \\
\text { quickly..Augu } \\
t \text { st last } \\
\text { year...I'd } \\
\text { never sent } \\
\text { emails } \\
\text { before...[1986 } \\
\text { JI convinced } \\
\text { the others to } \\
\text { computerize } \\
\text { so we had } \\
\text { word } \\
\text { processing }\end{array}$ & $\begin{array}{l}\text { Because I just } \\
\text { basically put } \\
\text { stuff in. } \\
\text { Saying } \\
\text { research is a } \\
\text { stretch. I just } \\
\text { Google things } \\
\text { and see what } \\
\text { comes up } \\
\text { really. }\end{array}$ & 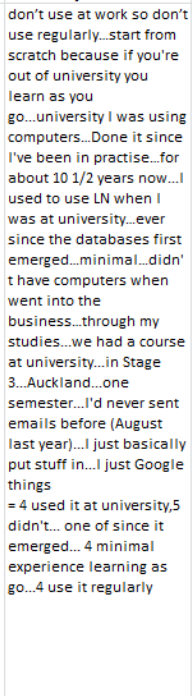 & $\begin{array}{l}\text { (Ingwersen) Factors that have impact } \\
\text { on process: Background experience: } \\
\text { Teaching themselves Although four } \\
\text { used it at university only one had } \\
\text { extensive training on it. Two have } \\
\text { undertaken courses either with } \\
\text { librarians at uni or having someone } \\
\text { come around to their home and } \\
\text { three had had training from the } \\
\text { specialised legal database } \\
\text { companies on how to use their } \\
\text { product. Of the three that have had } \\
\text { no training and no access to legal } \\
\text { databases they say that they either } \\
\text { undertake very little research or } \\
\text { they just Google information. }\end{array}$ \\
\hline
\end{tabular}


Appendix I: Characteristics of participants sample

\begin{tabular}{|l|l|l|}
\hline Frequency Table showing age of participants & $n$ & per cent \\
\hline $25-29$ & 2 & $22.2^{*}$ \\
\hline $35-39$ & 1 & $11.1^{*}$ \\
\hline $40-44$ & 2 & $22.2^{*}$ \\
\hline $45-49$ & 1 & $11.1^{*}$ \\
\hline $50-54$ & 1 & $11.1^{*}$ \\
\hline $60-64+$ & 2 & $22.2^{*}$ \\
\hline TOTAL & 9 & 100 \\
\hline & & \\
\hline & & \\
\hline Frequency Table showing sex of participants & & $55.5^{*}$ \\
\hline Male & 5 & $44.4^{*}$ \\
\hline Female & 4 & 100 \\
\hline TOTAL & 9 & \\
\hline & & \\
\hline & & $33.3^{*}$ \\
\hline Frequency Table showing years of legal experience & & $22.2^{*}$ \\
\hline 0 to 4 & 3 & $11.1^{*}$ \\
\hline 5 to 9 & 2 & $33.3^{*}$ \\
\hline 10 to 14 & 1 & 100 \\
\hline 20 and over & 3 & \\
\hline TOTAL & 9 & \\
\hline & & \\
\hline
\end{tabular}

